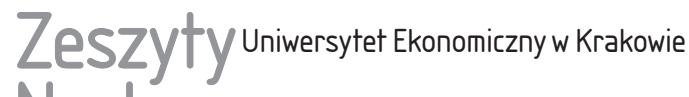 Naukowe
}

\author{
Anna Gapys \\ Doctoral Studies of the Economics \\ and International Relations Faculty \\ Cracow University of Economics
}

\section{Analysis of Shale Gas Exploration and Production Regulations - Lessons from Poland, Canada and the US}

\begin{abstract}
The aim of this paper is to review the theoretical and practical aspects of regulations concerning the exploitation of natural resources. Raw material policy is a public project, and therefore a decision tool known as Cost Benefit Analysis (CBA) should be applied.

A nation's ownership of minerals is in practice frequently contested. Non-democratic governments have very often sought to collect revenues from natural resource exports in order to build their private fortunes. Such abuses are observed even today.

The article begins with a short theoretical discussion about CBA. It then presents the issue of ownership of natural resources from the perspective of international law as well as the phenomenon of resource nationalism. The following section looks at the policy of granting concessions, a common tool used in regulating access to raw materials for exploration and production $(\mathrm{E} \& \mathrm{P})$ companies.

The empirical part of the paper analyses shale gas regulations in Poland, while also examining both the restrictiveness of rules adopted in this country and the legal preparedness of the Polish authorities to begin to use shale gas on a mass scale. Key findings of this part are enhanced with lessons from shale gas production in the US and Canada.
\end{abstract}

Keywords: Cost Benefit Analysis (CBA), raw material policy, concessions, regulation methods. 


\section{Cost Benefit Analysis - Theoretical Aspects}

The exploitation of raw materials, benefits obtained from selling them and revenue redistribution are perceived as public projects. That is a result of not only the great influence exports of natural resources exert on the socio-economic situation of given countries but also the nature of the resources themselves. They are a given territory's natural wealth, suggesting they should be treated as national treasure.

However, because mineral resources are non-renewable, there are numerous theories concerning the propriety and proper pace at which they should be used as well as intergenerational solidarity.

Cost benefit analysis (CBA) is a decision tool that contributes to a higher level of social well-being. Its mechanism implicates rational debate about both the soundness of particular public projects and the evaluation of their results. CBA provides wide understanding of the conflict between different stakeholders and also ensures transparency in decision-making on the part of public authorities. The effects of using CBA are also referred to as the "social well-being triad", which includes: more competitive markets, more market in the state's activity and more voluntary collective action on the part of individuals instead of state intrusion (Surdej 2008, p. 125).

The drawback of applying cost benefit analysis, however, is that it can be difficult to present some aspects of of a given decision in the form of a financial value. This pertains especially to benefits, as a project's costs are, in general, easily calculable. Evaluating the cost of benefits or lost benefits is far more complicated, especially when a longer time horizon is considered. The indicator known as willingness to pay may be applicable in estimating benefits. This measure is expressed by two values: the first one indicates the maximum value that individuals are willing to pay for a particular policy's consequences that are perceived as positive. The other is the minimum value individuals are willing to accept as compensation for consequences perceived as negative. In the latter case the mechanism of income distribution in a society plays a significant role (Surdej 2008, p. 122).

The exploitation of natural resources involves not only decision-making in the area of income redistribution but also leads to the destruction of the environment. CBA addresses these issues by introducing active and passive utilisation, ownership benefits and existence preservation benefits. For natural sites, a valuation known as contingent valuation - where a representative group of respondents indicate the costs they are willing to bear in order to preserve the site - is also sometimes applied. However, this approach is strongly criticised as it assumes interviewees possess extensive knowledge about the particular cost. Moreover, it 
does not account for consciously false answers given by respondents seeking to influence final decisions in a given project (Surdej 2008, p. 114).

However, it is not my intention to provide a detailed presentation of cost benefit analysis here. Suffice it to say that, though this tool has many imperfections, better ones do not currently exist, and the situation is unlikely to change for the foreseeable future.

\section{Raw Materials Ownership in the Light of International Legal Principles}

So, given that natural resource exploitation can be perceived through the lens of public projects, it is apposite to also analyse the issue of the ownership of raw materials. This is to say, the entity that owns mineral deposits located in a particular country - the authorities, nation or individual - should be made public. Doing so opens up further issues that need to be resolved. Once exploitation has begun, questions about concession fees, mining usufruct fees and environmental taxes arise. The state's goal should be to secure its position without violating the right of foreign investors to fair profits from their exploration and production (E\&P) activity. The above matters are key factors in regulations governing raw material exploitation.

From the perspective of international law, natural resource ownership is defined by the rule of Permanent Sovereignty over Natural Resources (PSNR), the notion of which originated with General Assembly Resolution 626 (VII) of December 21, 1952. It gained greater justification in 1962, when General Assembly Resolution 1803 (XVII) declared that permanent sovereignty over natural resources is applicable both to people and whole nations (Gess 1964). The legitimacy of this rather political declaration at first raised a great deal of controversy. Nevertheless, over time the common practice of international law transformed PSNR into rightful rule. While the legal status of this principle is no longer contested, the number of different interpretations of it has grown. They can be categorised into three groups (Duruigbo 2006, p. 38-39).

The first one grants the right to benefit from applying PSNR to states or de facto to the authorities of the particular country. This interpretation, however, too often led to abuses of privilege. As a result, revenues from exploitation of deposits were often used to build private fortunes of dictatorial leaders - a situation observed in, among other places, Iraq under Saddam Hussein.

The second line of interpretation of PSNR stresses the nation's right, while the third combines both the first and second approaches and declares that the above principle refers to the sovereignty of the nation, on behalf of which it is applied by 
the state's authorities, who act only as the guardians of mineral deposits. Distinguishing clearly between the citizen's right and government's responsibility - and to avoid the potentially kleptocratic inclinations of the latter - poses a challenge to international law (Duruigbo 2006, p. 37).

How the right to exercise permanent sovereignty over natural resources is understood greatly influences the redistribution of revenues derived from mineral resources. Supporters of the interpretation favouring citizens seek to push through projects in which revenues from the sale of minerals are equally shared among all adult citizens. Money would then be transferred to their registered accounts, with the sum ranging from 10-40\% of one's average salary. Proponents of this approach argue that this additional cash flow would, in resource-rich countries, be able to replace risk-averse credit institutions, thus contributing to the rise of entrepreneurship among citizens. However, this scenario has some clear weaknesses, which is why it has gained less popularity than special civil funds, where some of the revenues from raw material exports would be transferred (Duruigbo 2006, p. 78-79). Like in Norway, those funds could constitute one pillar of the pension system in a given country.

\section{Resource Nationalism as a Risk Factor for the Mining Industry}

Regardless of the interpretation described in the previous paragraph, PSNR rule, resource nationalism is still commonly observed, and therefore it is seen as a political risk by investors planning E\&P activities. R.W. Click and J. Weiner (2010) have evaluated the real cost of this risk. Results of their research conducted in 37 resource-rich countries confirmed, among other things, that a single-point drop in the International Country Risk Guide Index (ICRG) translates into 2.5-2.9\% increase in the price of a barrel of oil (Click \& Weiner 2010, p. 799).

Political risk arising from resource nationalism also has much wider implications. The cost of that risk is an important component of cost-effectiveness analysis in the case of mergers and acquisitions in the markets. Further, Click and Weiner claim, on the basis of empirical findings, that political risk is interrelated with the market risk. This means that the higher the value of the raw material resulting from better market conditions, the bigger the portion of it that will be destroyed by political risk. To give an example, at a price of 25 USD per barrel of oil, the discount on reserves in Russia equals $52 \%$, according to the ICRG index, whereas at a price of 40 USD, it increases to $88 \%$ (2010, p. 799). Thus the negative influence of political risk on the prices of raw materials is considerable.

Resource-rich countries periodically resort to nationalism when it comes to their mineral reserves. In 2006 alone the petrochemical industry in Bolivia was 
nationalised, troops were used to take over the Occidental Petroleum company in Ecuador, Chadian authorities established the state oil company while rebuffing its two biggest foreign investors - Chevron and Petronas - in the process. Meanwhile, the Russian authorities forced contract renegotiations that deprived BP and Shell of majority stakes in their Russian projects, and in Venezuela authorities forced two investors - Exxon and ConocoPhillips - to sell their assets compelling both to pull out of the country (Click \& Weiner 2010, p. 783-784).

Apart from resource nationalism, there are a few other risk factors worth noting. One is the dependence on international institutions controlling the production of raw materials. For example, OPEC, whose share in the oil market exceeds 50\% and is still rising. Attempts to minimise OPEC's influence on western countries' policies have yet to be crowned a success (Rose 2004, p. 441). The dictate of institutions such as OPEC and the inability to quickly find alternative supply sources should be another important thread of the debate regarding mineral regulation.

\section{Concessions as a Tool for Regulating the Mining Industry}

Apart from risk factors, some achievements in regulating raw materials exploitation should be recognised. One of them would be concessions, a tool to increase competition and an alternative to privatisation (Concessions 2008, p. 10).

A concession is the right of a private entity to use the state's infrastructure and revenue from it under certain conditions. It is applied where privatisation is not possible, like in the mining industry. The first step that must be taken when seeking a concession is to prepare a draft of the concession, which should maximise the competitiveness of the particular area to which the concession applies. The granting of concessions is also a critical act, as doing so causes investors to compete with one another. However, the final costs and benefits of granting concessions have not been fully established. This opens the field for the renegotiation of concessions, which usually negatively affects the process of their use (Concessions 2008, p. 11).

Two main types of concessions are commonly used:

1) lease and operate - in which a private contractor is responsible for providing a particular service and the use of existing infrastructure in exchange for a lease fee,

2) concessions in the strict sense - in which this same private contractor has yet to finance construction of the entire investment. After the concession has expired, assets are transferred to the public entity.

Concessions may also be described by the following formulas:

- BOT (build-operate-transfer) - usually applied to concessions regarding greenfield investments, 
- ROT (refurbish-operate-transfer) - used in investments more often concerning infrastructure modernisation than construction,

- BOO (build-own-operate) - used when transfer of the assets to the public body is not provided.

When talking about concessions, the term divestiture should also be explained. It describes the situation in which the ownership of public assets is transferred to the private sector together with the responsibility for their future maintenance (Concessions 2008, p. 17).

Concessions may also be sold in order to ensure an additional source of income for the state. Here tenders, of which there are four types, are usually organised (Concessions 2008, p. 20):

1) ascending-bid auction (known also as an English auction or open ascendingbid auction) - in which the item is sold to the highest bidder,

2) descending-bid auction (known also as a Dutch auction or clock auction) - in which the price starts from a relatively high level and then is gradually lowered until it is accepted by one of the bidders,

3) first-price sealed-bid auction - in which all bids are handed to the auctioneer in a sealed envelope. The highest bid wins, and the bidder pays the exact amount indicated in his bid,

4) second-price sealed-bid auction - analogous to the previous one. However, the winner with the highest bid pays not the price indicated by his own but the amount equal to the second highest bid,

Concession-granting mechanisms, strategies related to this process and further contract renegotiations or enforcement of competition on the concession areas are definitely an interesting question. However, due to space limitations, no further elaboration is presently possible.

In any case, widely used in the exploitation of minerals, concessions have given Poland problems, which will be discussed in the empirical part of this paper.

\section{Minimising the Risk of Concessions by Contractors}

Concessions for the exploration and mining of minerals generally take the form of long-term contracts, which are signed for several years or longer. The risk of diametrical change in legislation or government, armed conflicts and, above all, frequent economic crises is fairly high. Hence investors try to minimise the risk associated with the investment and secure their business in the best way possible. Much depends on the type of contract signed with the government of the country in which the project is to be implemented. 
Table 1 presents the main types of contracts, including the risk borne by the host country as well as the main sources of expected income for the host country and the contractor.

Table 1. A Comparison of Contract Structures

\begin{tabular}{|l|l|l|l|}
\hline $\begin{array}{c}\text { Host state's control } \\
\text { on operations and } \\
\text { example country }\end{array}$ & Host state's financial risk & \multicolumn{1}{|c|}{$\begin{array}{c}\text { Host state's main } \\
\text { revenues }\end{array}$} & $\begin{array}{c}\text { Contractor's } \\
\text { main revenues }\end{array}$ \\
\hline $\begin{array}{l}\text { Leases / licences / } \\
\text { concessions (UK, } \\
\text { Australia, Thailand) }\end{array}$ & $\begin{array}{l}\text { Low (host state has no direct } \\
\text { participation in exploration / } \\
\text { production) }\end{array}$ & $\begin{array}{l}\text { License fee/signing fee, } \\
\text { royalty, business tax, } \\
\text { production bonuses }\end{array}$ & Production \\
\hline $\begin{array}{l}\text { Production Sharing } \\
\text { Contracts (Indonesia) }\end{array}$ & $\begin{array}{l}\text { Medium (contractor explores } \\
\text { at sole risk, host state and } \\
\text { contractor jointly bear mar- } \\
\text { ket and price risk) }\end{array}$ & $\begin{array}{l}\text { Signing fee, sharing } \\
\text { of profit oil, royalty, } \\
\text { business tax, production } \\
\text { bonuses }\end{array}$ & Production \\
\hline $\begin{array}{l}\text { Service Contracts } \\
\text { (Iran) }\end{array}$ & $\begin{array}{l}\text { High (contractor explores at } \\
\text { sole risk, host state typically } \\
\text { bears most of the market } \\
\text { and price risk) }\end{array}$ & $\begin{array}{l}\text { Production, business tax, } \\
\text { production bonuses }\end{array}$ & $\begin{array}{l}\text { Service fee out } \\
\text { of production }\end{array}$ \\
\hline $\begin{array}{l}\text { Technical Assistance } \\
\text { Contracts }\end{array}$ & $\begin{array}{l}\text { High (usually involving tech- } \\
\text { nical assistance for a specific } \\
\text { phase of the project and is of } \\
\text { a shorter term) }\end{array}$ & Production, business tax & Service fee \\
\hline
\end{tabular}

Source: Howell, Loh \& Yuen (2009).

Apart from contract structure, risk factors for potential investors include: taxes, mining fees, additional charges and, last but not least, resource nationalism. Thus it is common practice among contractors to include a stabilisation clause in the contract with the host country. Its goal is to prevent legal changes from occurring in the country during the course of an ongoing project. However, this clause has been criticised for limiting the sovereignty of states as well as human rights in areas such as health and the environment. Therefore, the modern approach favours an economic equilibrium clause. Application of this clause means that in the case of administrative changes adverse to the investor, both sides - the host country and investor alike - are obliged to find a new equilibrium point and rebalance the economic benefits (Howell, Loh \& Yuen 2009).

Another option towards enhancing investment security for contractors is Bilateral Investment Treaties (BIT). These state-to-state agreements are aimed at providing investors with some guarantees from the country of origin in the territory of the host country. Such guarantees may include equal treatment and free cash flow, to name two. Bilateral investment agreements typically allow the use of 
the dispute settlement mechanism under the auspices of the International Centre for Settlement of Investment Disputes (ICSID) (Howell, Loh \& Yuen 2009).

\section{Shale Gas in Poland - Reserves, Potential and Regulatory Issues}

The empirical part of this study will demonstrate the problem of shale gas exploitation in Poland. The analysis mainly covers the legal aspects of granting exploration and production $(\mathrm{E} \& \mathrm{P})$ concessions. This section will be complemented by conclusions derived from the experience of Canada and the US in extracting shale gas.

\subsection{Poland's Former Experience in Regulating the Exploitation of Raw Materials}

It should first be noted that Polish authorities have little experience in regulating E\&P activity, for the simple reason that until now there have been no foreign investors interested in the country's natural resources, which would report accession to the tenders and concessions. Hence the country lacks both experience in dealing with them and the appropriate legal regulations. Moreover, the science backing the regulatory issues has not been done. Thus selected publicist articles are necessarily treated as a source of knowledge.

The taxation of mineral resources in Poland is quite a difficult issue. The lack of experience and a vague, incomplete and outdated legal system are the two main problems, but not the only ones. Despite their widespread use around the world, mining taxes are a relatively new concept in Poland. As a shareholder of mining companies, the state makes money in the form of dividends. However, it very often must also bear the risk and burden of restructuring mining companies. Coal mines are a good example here. This sector's rationalisation costs fell in fact on taxpayers. However, if taxpayers participate in the costs of exploiting natural resources, does it not stand to reason that they should also reap their share of the profits earned? Having embraced that logic, the Polish authorities are striving to guarantee such participation by imposing a new tax.

As of the writing of this article, entrepreneurs from the mining industry had to cover the following costs: exploration concession fees, production fees (about 4 per mille of the value of the ore), environmental and operational fees, which are transferred to municipalities and National Fund for Environmental Protection and Water Management. The latter fees are treated as compensation for environmental destruction. They are usually seemingly symbolic - for copper it is about PLN 3 per tonne of ore, which, however, annually yields PLN 90 million. 
Professor Stanisław Gomułka, chief economist at the Business Centre Club (BCC), highlights three types of taxation on minerals (Kurasz, Roguski \& Baca-Pogorzelska 2011):

1) unit base (for example per tonne of copper),

2) ad valorem (as a percentage of a mineral's market value),

3) profit-based (as a percentage of profits made, preferred by entrepreneurs in the industry).

The first steps towards taxing minerals have already been taken. The Act of March 2, 2012 legally regulates the tax on the extraction of silver and copper. Section III of this act specifies the method of calculating the tax, taking into account not only the size of production, but also, among other things, the average price of natural resources in the London Metal Exchange (LME) stock market (Ustawa o podatku... 2012)

Experts suggest that the above act is only the beginning of the regulatory process, which should also take into account the unique challenge presented by extracting particular raw materials and whether its deposits are already exposed (copper) or still untapped (shale gas). In extreme cases the legal status of mineral ownership should be secured as well. For example, brown coal in Poland is now legally possessed by the owner of the land. This is a result of legislative neglect in the past. The Polish state regained control over this resource in January 2013 (Dziadul 2011).

\subsection{Shale Gas in Poland - Reserves and Potential}

Presentation of the current estimates of shale gas resources in Poland will help to better illustrate the importance of creating an appropriate legal framework for their exploitation. Polish annual demand for gas is about 14.3 billion $\mathrm{m}^{3}$. However, only a third of blue fuel comes from domestic production. This unfortunately renders Poland dependent on gas imports, especially from Russia, which is a difficult partner in negotiations for a variety of reasons. Monopolistic practices, the politicisation of the financial terms of supply together with new gas pipelines built outside of Polish territory have all combined to greatly emasculate Poland's energy security (Gapys 2010).

There are various estimates of Poland's shale gas reserves, ranging from 346 billion $\mathrm{m}^{3}$ to 1.9 trillion $\mathrm{m}^{3}$ (according to the Polish Geological Institute), 1.4 trillion $\mathrm{m}^{3}$ (according to Wood Mackenzie) and even 5.3 trillion $\mathrm{m}^{3}$ (by the U.S. government agency Energy Information Administration) (Gaz łupkowy... 2012).

The above figures are only probable, as they are based on the assumption that a great part of Polish territory is a suitable substrate for shale gas. Thus, 
there is a high probability that shale gas is present, but the actual resources will only be confirmed after drilling about 100 wells. The "shale gas belt" represents almost $12 \%$ of Polish territory, and includes the Pribaltic, Podlasie and Lublin regions, the first of which is considered the most promising. By September of 2012, 25 wells had been drilled and 12 more were in progress (see Fig. 1). There are also another 20 wells whose implementation is to begin before the end of 2012. For the period running to September 2012, the Ministry of the Environment has issued a total of 111 licenses. The biggest beneficiaries to date have been the state-owned PGNiG (15), Petrolinvest (14), Marathon Oil Company (11), 3leg resources (9), Orlen Upstream LLC (7) and BNK Petroleum (6) (Podmioty posiadajace... 2012).

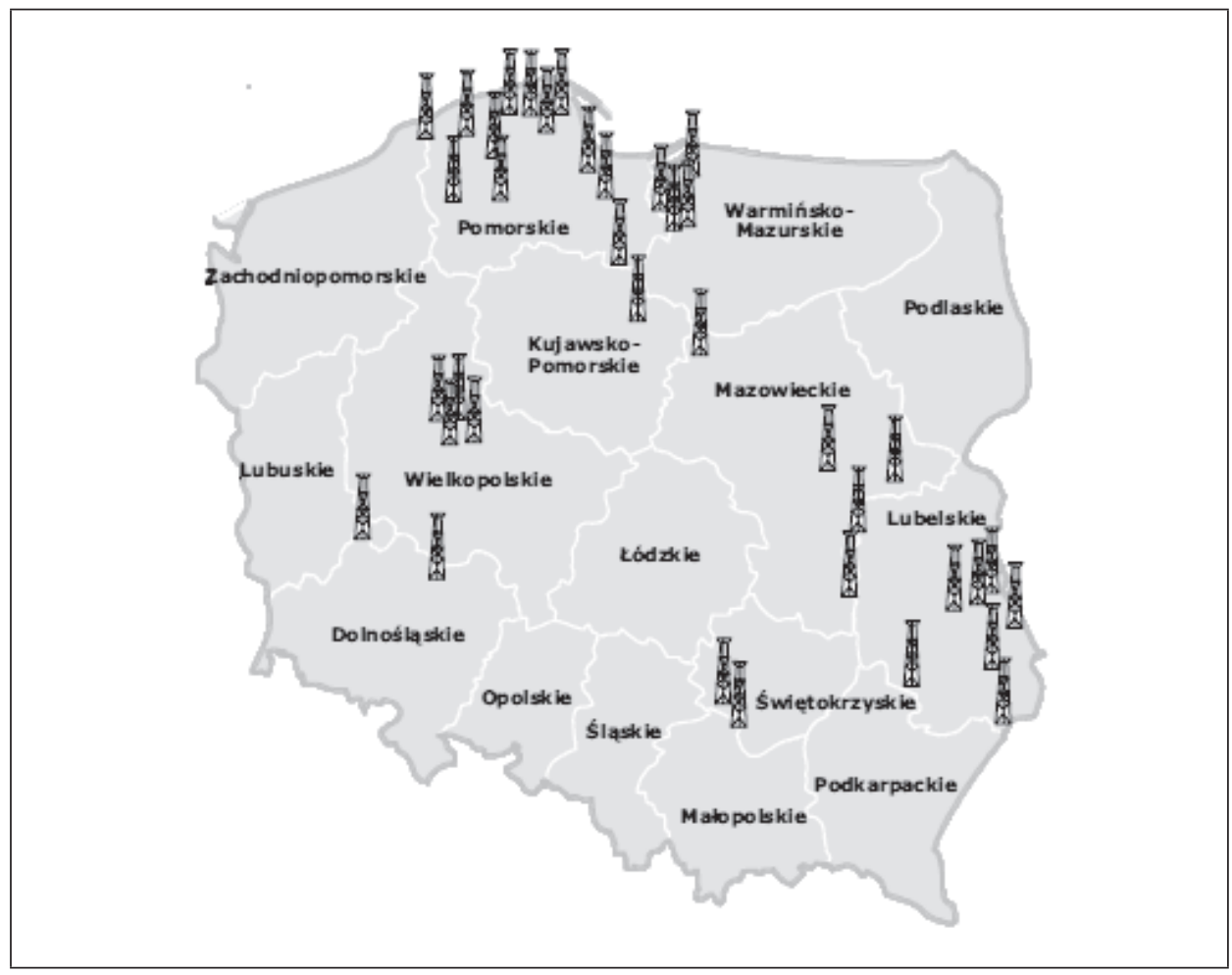

Fig. 1. Wells Drilled (Completed or Commenced) to Date, August 2012 Source: Gaz tupkowy w Polsce (2012).

The first more reliable information about shale gas deposits in Poland is expected as soon as necessary number of wells are drilled (about 100). However, confirmation of even the slightest of the projected reserves (346 billion $\mathrm{m}^{3}$ ) 
would completely eliminate the need for gas imports for roughly 30-50 years, as domestic blue fuel exploitation would satisfy the country's demand ( $\mathrm{Gaz}$ tupkowy... 2012). The above data clearly indicate the importance of properly regulating shale gas exploitation.

\subsection{Exploration and Production of Shale Gas in Poland from the Perspective of Investors}

Apart from the above problems with regulating shale gas, the view of investors should also be presented in this study. The Polish state does not have sufficient funds to seek and extract shale gas. The cost of drilling a single well is the cost of USD 15-20 million. There is no doubt that the state will benefit from shale gas production in the form of taxes, but the tax system and governing bodies should be transparent and clearly define their prerogatives. Poland has not done that for several reasons.

First, the legal framework and construction of government policies are lagging behind practice. The concessions' provisions are still not entirely clear, even though more than 100 have already been issued. It is worth noting that the concessions are not profit-motivated from the state's point of view. Chief geologist of the country, Henryk Jacek Jezierski, explains that the moment to reap the profits will come once the size of the deposits is confirmed. For now, investors should be encouraged to undertake E\&P projects. Whatever the reasons for the delay in determining the concessions, it remains a fact. Nevertheless a change in the concession-granting terms at this time could jeopardise the state's treasury, as investors holding concessions could take legal steps to fight for compensation (Ostrowski 2011).

Another crucial issue for investors is the method of amortisation used for the investments. As noted by Marcin Rudnicki (KPMG Poland), the total return on investment (ROI) in Polish shale gas is expected over a period of 20-25 years. Moreover, because the first years of the investment are especially difficult, the state should help investors to survive this period. In the opinion of M. Rudnicki, a five-year period to settle tax loss is far too short and therefore should be extended. He also lists two additional risk factors for investors that need to be addressed. The first is uncertainty as to how to allocate the costs of investment, while the second is the fact that the Geological and Mining Law Act, despite being amended on 1 January 2012, is still incompatible with the current requirements. Among the positive factors that provide incentives for investments, Mr. Rudnicki pointed to announcements regarding the creation of a separate Hydrocarbon Act as well as the establishment of a Hydrocarbon Fund (Ciechanowska 2012). 
Last but not least, there is one final significant aspect, which has not received binding regulation - the guarantee of a smooth transition between the exploration and production stages for entities that have engaged their resources and confirmed reserves of a natural resource. At the moment there is no guarantee that companies engaged in the exploration of deposits will be granted a concession for production. The Polish authorities would be well-advised to solve this problem. However, this is a very negative message to potential investors. The adverse tone of these provisions is alleviated by the fact that the entity conducting the search shall have the exclusive right to use the information obtained in this way for a period of five years from the concession's expiry date. This means that for five years from the discovery of the deposits, the Polish authorities are prevented from publishing a tender for mining, otherwise they would have to reveal information owned by the discoverer of the deposits (Rutkowska-Subocz 2011).

The above shows that investors have clearly defined expectations which the government has failed to address.

\section{Experience of Other Countries in Regulating Shale Gas}

The difficulties the Polish authorities face in properly regulating the extraction of shale gas have been unquestionably demonstrated above. I shall now look at the experience of countries that for many years have been exploiting both natural and shale gas, namely Canada and the US.

\subsection{Canada - Lessons from Gas Exploitation}

Canada is one of the leading global suppliers of natural gas. It extracts unconventional natural gas in the form of shale gas, tight gas and coal-bed methane (CBM). The country has regulated the exploitation of minerals on two levels: regional and federal. The rationale for this may be found in the following two theories:

1) race-to-the-bottom - where the regional authorities reduce regulatory requirements on environmental protection below a certain optimum level, for fear of migration of the particular industry to the region, with more favourable economic conditions. This case is a prerequisite for the creation of a federal regulation (Sarnoff 1997);

2) interstate externalities - occur when the negative effects of the economic activity in one region spread to neighbouring areas. In this case, however, the region emitting the effects benefits from those activities, while not fully participating in the costs related to them. In this case, a federal adjustment is essential (Revesz 1996-1997). 
The above theories, while not free of drawbacks, are a theoretical justification for regulating gas deposits in the State of Alberta. These four key lessons that come from the operation of the Canadian minerals are also worth considering (Jefferies 2012, p. 109-114):

1. The scientific evaluation and transparency of the performance are of great importance. The possible effects and risks in exploiting minerals should be assessed before industry is permitted to enter. Polish regulations, however, are not able to keep pace with the rapidly evolving situation in shale gas exploration.

2. The separation of the regulator and operator should be legally sanctioned.

3 . The role of statewide (federal) authorities in the regulation process is significant.

4. Because the national authorities can be heavily influenced by the industrial lobby or other political pressures, the exploitation of raw materials should be managed at the regional level.

Polish legislators will soon have to face up to these issues, with the environmental aspect being of paramount importance. Natural gas exploitation in Canada has visibly destroyed the environment. However, mining in Canada is most often conducted in desolate areas, while that would not be possible in Poland, given the location of the deposits. Therefore the need to resolve those matters prior to starting an operation on a production scale is of the highest importance.

\subsection{Class Actions as an Expression of Social Protest in the United States}

Potential producers of shale gas are aware of the impact of the American public on mining projects. Their two biggest associations, the Pennsylvania Oil \& Gas Association (POGAM) and the Independent Oil \& Gas Association of Pennsylvania (IOGA of PA), have created a joint committee whose goal is to convince local residents that extraction projects around the Marcellus shale bed are in their interest. The Committee not only runs an open debate on the potential impact of shale gas, but also tests new production methods and actively seeks constructive solutions such as the possibility of recycling waste. However, both parties are coming to realise that the actual consequences of extraction can be assessed only after the mining projects are launched (Snow 2008).

Despite a series of discussions and meetings, the general increase in knowledge about hydraulic fracturing has caused American society to react with a great deal of emotion. This is due to the potential risks to the environment, and thus to human health. There is a great deal of concern about the contamination of ground-water, which provides water for drinking and other domestic purposes. The scale of the threat has led individual communities to organise themselves and submit class action suits in three states: Pennsylvania, New York and West Virginia. 
The following threats to groundwater are mentioned in those class actions (Defending Marcellus... 2012, s. 155-161):

- significant reduction of water resources,

- leakage of fracturing fluid into the soil during transport or improper handling of on-site wells,

- leaking containers,

- contamination of groundwater by abandoned wells,

- use of substances other than water and sand in the fracking process,

- defective protection of fracturing fluid used in tanks and wells.

The foregoing class action suits clearly show that the level of public concern relating to the use of shale gas is high. And although the procedure itself requires that a number of simultaneously occurring conditions be proved, there is a risk that the Court will consider complainants' arguments, and orders a stop to the extraction of shale gas in a particular location.

In Poland the tradition of class action lawsuits is much less significant, but it is nonetheless worth preparing for this type of situation, so that citizens have the legal tools to defend their interests.

\section{Conclusions and Recommendations for Further Research}

This article is intended to be a general outline of the issues and certainly does not exhaust a number of interesting questions. At a later stage, a more detailed analysis of the experience of other countries in managing minerals should be done. Examining the countries experiencing the negative effects of extracting resources - for example, in the form of Dutch disease - will certainly be useful, as will researching countries such as Russia, which, even though it is very different from Poland in terms of legal conditions, has a great deal of experience in exploring various types of minerals.

This study has undoubtedly proved that Poland's potential shale gas reserves are a great opportunity for the Polish economy to develop. For this to happen, however, proper management of shale gas deposits is needed. It is therefore necessary to create a clear legal framework for E\&P activities as well as effective regulation tools, in order to protect not only the interests of all parties, but also to ensure that the environment is safe and future generations will share in the profits. This is unquestionably a challenging task, hence there is a need for a broad debate on the subject with the participation of experts from industry. At the same time, it is worth remembering that solutions used elsewhere - Canada, for example - may not necessarily fit the conditions in Poland.

Nevertheless, Polish society is open to extracting shale gas, seeing it as a great opportunity not only for the country's economy but also for the people, with benefits 
for the individual, in the form of lower gas prices. It is therefore of the utmost importance that this support not be lost through negligence or reckless decision-making.

\section{Bibliography}

Ciechanowska, E. (2012), W jaki sposób najlepiej opodatkować wydobycie gazu łupkowego w Polsce? "Dziennik Gazeta Prawna", 6 August, http://www.kpmg.com/pl/pl/ issuesandinsights/articlespublications/strony/w-jakis-posob-najlepiej-opodatkowacwydobycie-gazu-lupkowego-w-polsce.aspx (31.12.2012).

Click, R. W. and Weiner, R. J. (2010), Resource Nationalism Meets the Market: Political Risk and the Value of Petroleum Reserves, "Journal of International Business Studies", nr 41.

Concessions (2008), "OECD Journal, Competition Law and Policy”, vol. 1-2.

Defending Marcellus Shale Groundwater Contamination Claims: The Case against Class Actions and Other Theories of Liability, R. G. Mullady Jr, S. J. Doyle, Ch. A. Fitzpatrick IV, A. M. Guarino (2012), "Defense Counsel Journal”, vol. 79, nr 2.

Duruigbo, E. (2006), Permanent Sovereignty and People's Ownership of Natural Resources in International Law, "The George Washington International Law Review", vol. 38, nr 1 .

Dziadul, J. (2011), Podatek od surowców - czy to ma sens? "Polityka", 7 December, http:// www.polityka.pl/rynek/gospodarka/1521729,1,podatek-od-surowcow---czy-to-masens.read\#ixzzltkNgDb98 (31.12.2012).

Gapys, A. (2010), Ekspansja i działania monopolistyczne Gazpromu - wnioski dla Polski, „Nauka i Gospodarka”, nr 3.

Gess, K. N. (1964), Permanent Sovereignty over Natural Resources: An Analytical Review of the United Nations' Declaration and Its Genesis, "International and Comparative Law Quarterly", vol. 13.

Howell, A., Loh, P. K. and Yuen, P. (2009), Tips on Dealing with Concessions, "International Financial Law Review", Euromoney Trading Limited, London.

Jefferies, C. (2012), Unconventional Bridges over Troubled Water - Lessons To Be Learned from the Canadian Oil Sands as the United States Moves to Develop the Natural Gas of the Marcellus Shale Play, "Energy Law Journal”, vol. 33/75.

Kurasz, J., Roguski, A. and Baca-Pogorzelska, K. (2011), Podatki od kopalin słuszne, ale..., "Rzeczpospolita", 30 November, http://www.rp.pl/artykul/762253.html (31.12.2012).

Ostrowski, R. (2011), Należne za znaleźne. Narodowy plan zagospodarowania złóż gazu tupkowego, "Polityka", 22 June, http://www.polityka.pl/rynek/gospodarka/ 1516340,2 ,narodowy-plan-zagospodarowywania-zloz-gazu-lupkowego.read?print=true\#ixzz25s0tfRTo (31.12.2012).

Podmioty posiadajace koncesje na poszukiwanie i rozpoznawanie ropy naftowej i gazu ziemnego - łacznie konwencjonalnych i niekonwencjonalnych (shale gas) (2012), Ministerstwo Środowiska, http://www.mos.gov.pl/g2/big/2012_09/3ce38279b5b982e918c4ee2c233f51ea.pdf (31.12.2012).

Revesz, R. L. (1997-1998), The Race to the Bottom and Federal Environmental Regulation: A Response to Critics, 82 MINN. L. REV.

Rose, E. A. (2004), OPEC's Dominance of the Global Oil Market: The Rise of the World's Dependency on Oil, "The Middle East Journal", vol. 58, nr 3. 
Rutkowska-Subocz, E. (2011), Poszukiwanie i wydobywanie gazu łupkowego i zaciśniętego w Polsce - aspekty prawne, "Czysta Energia”, nr 2.

Sarnoff, J. D. (1997), The Continuing Imperative (But Only from a National Perspective) for Federal Environmental Protection, „Duke Environmental Law \& Policy Forum”, vol. VII, nr 2.

Snow, N. (2008), Producers, Regulators Aaddress Marcellus Shale Gas Challenges, "Oil \& Gas Journal", vol. 106, nr 42.

Surdej, A. (2008), Metoda analizy kosztów i korzyści: imperatyw efektywności w politykach publicznych [w:] Środowisko i warsztat ewaluacji, PARP, Warszawa.

Gaz łupkowy w Polsce [Shale gas of Poland] (2012), PMR, http://www.pmrconsulting. $\mathrm{com} / \mathrm{pl} / \mathrm{a} 8 /$ gaz-lupkowy-w-polsce (31.12.2012).

Ustawa o podatku od wydobycia niektórych kopalin [Certain minerals extraction tax act] z dn. 2 marca 2012, Dz.U. RP isap.sejm.gov.pl/Download?id=WDU20120000362 \&type $=2$ (31.12.2012).

Ustawa prawo geologiczne i górnicze z dn. 9 czerwca 2011, http://www.mos.gov.pl/g2/ big/2011_07/856261f5941ef74d75680ba05043a9d9.pdf (31.12.2012).

\section{Analiza regulacji w obszarze poszukiwania i wydobycia gazu łupkowego na przykładzie Polski oraz Kanady i USA}

Celem niniejszej pracy jest zbadanie aspektów teoretycznych i praktycznych regulacji eksploatacji kopalin. Polityka w zakresie surowców mineralnych jako projekt publiczny powinna w przekonaniu autorki być przedmiotem zastosowania narzędzia decyzyjnego, jakim jest analiza kosztów i korzyści.

Władztwo narodu nad zasobami naturalnymi bywa w praktyce często kontestowane. W przeszłości niezwykle często dochodziło do zagarniania zysków z eksportu kopalin przez władze danego kraju. W krajach o ustroju niedemokratycznym dochody z wydobycia zazwyczaj budowały prywatne fortuny przywódców owych krajów. Także i dziś dochodzi do tego rodzaju nadużyć.

Praca rozpoczyna się teoretycznym ujęciem analizy kosztów i korzyści. W dalszej części poruszony jest temat własności bogactw naturalnych z perspektywy prawa międzynarodowego oraz zjawisko surowcowego nacjonalizmu. Następnie przedstawiono problematykę polityki wydawania koncesji, gdyż jest to powszechnie stosowane narzędzie regulacji poszukiwania i wydobycia zasobów naturalnych.

W części empirycznej omówiono problematykę gazu łupkowego na przykładzie Polski. Celem tej części była analiza stopnia regulacji eksploatacji gazu łupkowego i gotowości prawnej polskich władz do rozpoczęcia wydobycia na skalę produkcyjną. Z przeprowadzonych badań jasno wynika, że przygotowanie Polski do masowej eksploatacji łupków jest nikłe. Złożyło się na to kilka ważnych przyczyn, wśród których wymienić należy brak doświadczenia w kontaktach z inwestorami zagranicznymi oraz zaniedbania ustawodawcze sięgające jeszcze epoki PRL.

W końcowej części opracowania przedstawiono wnioski wynikające z doświadczeń Stanów Zjednoczonych oraz Kanady w zakresie eksploatacji gazu łupkowego.

Słowa kluczowe: analiza kosztów i korzyści (CBA), polityka surowcowa, koncesje, metody regulacji. 